\title{
The Policy For Handling Criminal Acts Of Insult/Hate Speech Or Damage Through Internet
}

\section{Didik Sudarmadi*) and Jawade Hafidz ${ }^{* *}$ )}

*) Prosecutor's Office of the Republic of Indonesia, E-mail: diksudarmadi99@gmail.com

**) Faculty of Law, Universitas Islam Sultan Agung Semarang

\begin{abstract}
The purpose of this study is to find out and analyze the legal policy of the Information and Electronic Transactions Law (ITE) on the handling of criminal acts of defamation via the internet in Indonesia, to find out the obstacles to handling it. This study uses a sociological juridical approach, with analytical descriptive research methods. The results of the study conclude that crime prevention efforts need to be pursued with a policy approach, in the sense that there is an integration between criminal politics and social politics and there is an integration between penal and non-penal crime prevention efforts. The obstacle faced by law enforcement officers today is how to capture cybercrime perpetrators in relation to the provisions of the applicable criminal law. Law enforcement officers are faced with difficulties in determining the qualifications of crimes given the difficulty of finding evidence. As well as solutions for resolving criminal defamation cases through electronic social media at the Indonesian Police in two ways, namely through penal facilities (repressive activities after the occurrence of a crime) and non-penal means, in the form of counseling for preventive actions.
\end{abstract}

Keywords: Crime; Defamation; Electronic; Information; Transaction.

\section{Introduction}

Crime can be interpreted criminologically and juridically. Crime in the sense of criminology is a human act that tarnishes the basic norms of society. This is intended as the actions of individuals who violate the rules that live and thrive in society. Juridical crime, i.e. an evil act or evil act in the sense of criminal law means that the crime is formulated in criminal regulations. ${ }^{1}$ For modern countries, the desire to effectively guarantee the rights of citizens and regulate the orderly state administration has prompted every country to adopt constitutionalism, including the regulation of laws regarding insults and defamation on the internet. ${ }^{2}$ The settlement of criminal cases is carried out through the evidentiary process, namely

\footnotetext{
${ }^{1}$ usril I A, Bambang Tri Bawono \& Ira Alia Maerani, Criminal Investigation of Motorcycle Stealing Goods. Law Development Journal ISSN : 2747-2604 Volume 3 Issue 1, March 2021, (169 - 174). file://C:/Users/win10e/Downloads/14866-35234-1-PB.pdf

${ }^{2}$ Adhe I smail A, Constitutionalism Concept in Implementation of Indonesian State Administration. Jurnal Daulat Hukum Volume 4 Issue 2, June 2021 ISSN: 2614-560X. http://jurnal.unissula.ac.id/index.php/RH/article/view/15737/5567.
} 
the prosecution process which is carried out directly in an experiment. ${ }^{3}$ In judicial practice, the process always begins with an arrest, detention, then being prosecuted by the public prosecutor, which ends with a judge's decision. ${ }^{4}$

In the practice of implementing the ITE Law, various cases have emerged with accusations of insult/defamation as a form of restraint on freedom of expression. These cases have resulted in reporting to the police, detention and imprisonment. Other consequences that arise also occur in the form of filing a lawsuit in court and apologizing as well as threats of expulsion from the institution where you work or school. ${ }^{5}$ There have been at least 71 cases of internet users charged with Article 27 paragraph (3) of the ITE Law, since the Act was enacted, and in 2014 the highest number of cases was 40 cases. $^{6}$

The police is a subsystem in the criminal justice system that is sufficient to determine the success and work of the entire system in providing services to the public. ${ }^{7}$ One of the phenomenal cases related to the use of Article 27 paragraph (3) of the ITE Law is the case of Prita Mulyasari. The case, which began when Prita went to the Omni International Hospital for treatment, was later sued in a civil manner and was convicted using the ITE Law and spent 3 (three) weeks in prison, starting with Prita's complaint regarding services from the Omni Hospital by sending a letter to custumer_care@banksinarmas .com and to other relatives under the title "Omni International Alam Sutra Hospital Fraud".

Then Prita sent the contents of her email to detik.com readers' letters. Based on the email containing the complaint, Prita was finally sued in a civil manner and reported to the police. ${ }^{8}$ Another interesting case is the case of M. Arsyad. Arsyad was named a suspect because of accusations of insulting him through BBM status, he was detained by the South and West Sulawesi Regional Police for a week, before his detention was suspended. ${ }^{9}$ Arsyad, an Activist for the Anti-Corruption Guards, was

\footnotetext{
${ }^{3}$ Ardito, Y P, Umar Ma'ruf \& Aryani Witasari. Implementation of Criminal Action Prosecution Online in Realizing Principle of Fast Prosecution, Simple \& Low Cost, Jurnal Daulat Hukum, Volume 4 Issue 2, June 2021 ISSN: 2614-560X. http://jurnal.unissula.ac.id/index.php/RH/article/view/15737/5567. ${ }^{4}$ Feri, S W, \& Arpangi. Settlement Policy of Criminal Actions which Performed by Children through Penal Mediation. Jurnal Daulat Hukum Volume 4 Issue 2, June 2021 ISSN: 2614-560X. http://jurnal.unissula.ac.id/index.php/RH/article/view/15737/5567.

5 "Kritik Kampus, Mahasiswa Semarang Dipaksa Mundur dalam http://www.tempo.co/read/news/2013/09/19/058514741/Kritik-Kampus-Mahasiswa-

Semarang-

Dipaksa-Mundur. Retrieved January 17, 2021.

6 "ICT: 71 Kasus Pidana Akibat UU

http://nasional.tempo.co/read/news/2014/11/16/058622226/ICT-71-Kasus-Pidana-Akibat-UU-

ITE. accessed on 17 January 2021.

${ }^{7}$ Nurfita A T, Sri Endah Wahyuningsih \& Arpangi. The Police Role in Investigating the Crime of Child Murder as a Result of Infidelity Relationships. Law Development Journal ISSN : 2747-2604 Volume 3 $\begin{array}{llllll}\text { Issue } & 1, & \text { March } & \text { 2021, } & \text { 96 }\end{array}$. http://jurnal.unissula.ac.id/index.php/ldj/article/view/14866/5481.

8 Iskandar "Kronologi Kasus Prita $\quad$ Mulyasari" http://www.kompasiana.com/iskandarjet/kronologi-kasus-pritamulyasari 54fd5ee9a33311021750fb34 accessed on January 17, 2021

9 "Polisi Bebaskan Penghina Hurdin " dalam http://www.tempo.co/read/news/2013/09/16/063513795/polisi-Bebaskan-Penghina-NurdinHalid accessed on January 17, 2021
} 
reported to the South and West Sulawesi Regional Police for allegedly defaming Nurdin Halid on his Blackberry Messenger Status. He wrote on his BBM Status "No Fear Nurdin Halid Corruptor!!! Don't choose the corrupt brother!!!"

From the several cases above, at least it provides an illustration, The existence of Article 27 paragraph (3) of the ITE Law, has been tested by the Constitutional Court The considerations and decisions of the Constitutional Court state that literally elements are publicly known, publicly known, or broadcast in Article 310 paragraph (2) of the Criminal Code cannot be applied in cyberspace, so it requires extensive elements, namely distributing and/or transmitting, and/or making it accessible. In addition, the Constitutional Court also stated that certain articles in the Criminal Code are considered insufficient to answer legal issues that arise as a result of activities in cyberspace. ${ }^{10}$

In the politics of criminal law, it is not easy to determine an act as a crime and must first go through several in-depth study processes. In addition to the study of acts from the point of view of criminology, it must also consider the purpose of the criminal law itself, the determination of undesirable acts, the comparison between the means and results and the capabilities of law enforcement agencies. ${ }^{11}$ Therefore, it is necessary to study in-depth strategic considerations regarding the application of punishment for criminal acts of humiliation via the internet. Moreover, it is related to criminal acts of humiliation/defamation in the provisions of Article 27 paragraph (3) of the ITE Law which leaves many problems, both in terms of the formulation of the crime, duplication of articles to the punishment which is much higher than the article of origin/genus of the offense.

The purpose of this study is to find out and analyze the legal policy of the Information and Electronic Transactions Law (ITE) on the handling of criminal acts of defamation via the internet in Indonesia, to find out the legal policy constraints of the Electronic Information and Transactions Law (ITE) regarding the handling of criminal acts of defamation via the internet in Indonesia, what is the legal policy of the Information and Electronic Transactions Act (ITE) regarding the handling of criminal acts of defamation through the internet in the future.

\section{Research methods}

The approach method used in this research is the sociological juridical method. The specifications in this study are analytical descriptive. Sources of data used in this study are primary, secondary, and tertiary data sources. Primary data sources are objects that are observed directly in the field and interviewed informants. Primary legal materials consist of: Act No. 19 of 2016 concerning amendments to Act No. 11 of 2008 concerning Information and Electronic Transactions. Tertiary legal materials consist of dictionaries, encyclopedias.

The data collection method used to obtain data that has a relationship with the object of research is interviews with resource persons and document review,

\footnotetext{
${ }^{10}$ The decision of the Constitutional Court on case No. 50/PUU-VI/2009 regarding the judicial review of Article 27 paragraph (3) of the ITE Law

${ }^{11}$ Agus Rahardjo, 2002, op.cit. p. 54
} 
while the data analysis method used is qualitative data analysis in this study including data reduction, data presentation and conclusions/verification.

\section{Results and Discussion}

\subsection{Information and Electronic Transactions Law (ITE) Legal Policy}

Non-penal efforts by the Ministry of Communication and Information have been carried out since the enactment of the ITE Law through intensive socialization to law enforcers and the public considering that this legislation has a new domain that is very virtual in nature and the socialization will continue and be improved. In addition, citizens are also given the right and opportunity to evaluate, observe and criticize the Act article by article if there is a substance that is contrary to the 1945 Constitution. Decision of the Constitutional Court Number 50/PUU-VI/2008 and Decision Number 2/PUU-VII /2009 dated May 5, 2009, states that Article 27 paragraph (3).

Thus, there is no need and no reason whatsoever for the public to feel anxious, traumatized and afraid to use telecommunications services and communicate electronically for the benefit of each community's activities. This appeal from the Ministry of Communication and Informatics needs to be conveyed so that there is no hesitation from the public to express their opinions openly as is often conveyed in the reader's complaint rubric or Dear Editor in various mass media, considering the current trend that more complaints are sent via email than sent via email postal service or other private courier service. This appeal needs to be conveyed openly to reduce public anxiety, because the laws governing the freedom of individuals or groups of people or institutions to obtain privacy in communicating electronically are very strong and have strict guidelines. Whereas then legal problems arise due to the contents of the electronic communication which are then opened for public consumption and cause resistance responses or objections from other parties, then this is another problem that is not directly caused by the ITE Law. ${ }^{12}$

So, apart from criminal law application (penal policy), prevention without punishment (non-penal) is possible. For this reason, it is necessary to pay attention to other policy alternatives, namely the non-penal approach. The non-penal approach is intended as an effort to tackle crime by using other means other than criminal law (non-penal). Crime prevention efforts using a non-penal approach are oriented towards efforts to deal with conducive factors that lead to crime. Examples of non-penal measures that can be used include education, recitation and other activities aimed at preventing crime.

\subsection{Legal Policy Constraints on the Information and Electronic Transaction (ITE) Law}

\footnotetext{
${ }^{12}$ http://media.kompasiana.com/new-media/2010/01/27/jangan-takut-menulis-dikompasiana/ accessed on July 1, 2021
} 
The problems faced by investigators in conducting investigations and collecting evidence against cyber crime cases are:

- Difficulty in detecting computer crimes. This is caused by: The security system of the computer itself is not sufficient; There is a reluctance of computer owners to report any incidents of computer abuse; Society has not played a major role in detecting computer crime.

- Evidence is easy to remove/destroy/destroy/delete.

- Investigations may be interrupted/delayed by system crashes.

- Records on the system can be modified so that evidence can be changed

- Computers can carry out anyone's orders, making it difficult to track down who the real culprit is. ${ }^{13}$

The evidence system in the current era of information technology faces big challenges that require serious handling, especially in relation to efforts to eradicate cybercrime. This arises because for some parties the types of evidence that have been used to ensnare criminals can no longer be used to ensnare criminals in cyberspace.

The problem of proving in criminal acts of defamation through the internet is closely related to the condition of the Criminal Procedure Code (KUHAP) which has not been revised. "The criminal justice system views the four law enforcement officers, namely the police, prosecutors, courts and correctional institutions as implementing institutions of applicable laws and regulations so that the four apparatuses are an inseparable part of the law enforcement system." 14

\subsection{Information and Electronic Transaction (ITE) Law Policies in the Future}

The legal policy of criminal defamation through electronic social media in this case is carried out by the police because the police are an institution which in the Criminal Procedure Code is authorized to carry out investigations and investigations. Investigation and investigation is an initial understanding of the legal process in criminal cases, starting from the process handled by the police as investigators and investigators as well as other officers in this case is PPNS as referred to in the provisions of Article 4 of the Criminal Procedure Code which reads Investigators are every state police officer of the Republic of Indonesia. In addition, what is meant by investigators is regulated in Article 6 paragraph (1) of the Criminal Procedure Code.

In the framework of the legal policy of criminal defamation through electronic social media, law enforcement steps for criminal defamation through electronic social media are carried out after complaints from the public that there has been a criminal act of defamation through electronic social media ${ }^{15}$.

In the investigation process, Police investigators are constrained by the identity of the reported party because the reported party is a Social Media Network

\footnotetext{
${ }^{13} \mathrm{Al}$ Wisnubroto.1999. Kebijakan hukum pidana dalam penanggulangan penyalahgunaan komputer,Universitas Widyatama, Yogyakarta, p. 256-257

${ }^{14}$ Andi Hamzah.1985. Pengantar Hukum Acara Pidana Indonesia. Ghalia Indonesia. Jakarta, p. 267

15 A Chuasanga, Ong Argo Victoria. (2019). Legal Principles Under Criminal Law in Indonesia \& Thailand, Jurnal Daulat Hukum, Vol $\quad 2, \quad$ No 1 (2019) http://jurnal.unissula.ac.id/index.php/RH/article/view/4218
} 
Account which is kept secret the identity of the account owner is unknown, in this case Indonesian Police investigators cannot summon the reported party. In the framework of the legal policy of criminal defamation through electronic social media, the Indonesian National Police make the following efforts:

- Preventive efforts, this preventive effort focuses on the element of prevention, meaning that countermeasures are carried out before the occurrence of criminal acts of defamation through electronic social media in the territory of Indonesia. The police as law enforcement officers in Indonesia have a public service duty, namely by protecting, protecting and nurturing the community. In carrying out its duties carried out with preventive efforts. As a form of this effort, the Indonesian police conduct socialization to the public regarding Article 27 paragraph (3) in conjunction with Article 45 of Act No. 11 of 2008 concerning Information and Electronic Transactions. In carrying out this effort, the Indonesian police disseminated Act No. 11 of 2008 through social media facilities integrated by electronic social media, namely through the Indonesian Police Facebook account.

- Repressive efforts to legal policy efforts after the criminal act of defamation through electronic social media occurred.

\section{Closing}

The conclusions in this study are the problems faced by investigators in conducting investigations and collecting evidence against cyber crime cases, namely: 1). Difficulty in detecting computer crimes. 2). Evidence is easy to remove/destroy/destroy/delete. 3). Investigations may be interrupted/delayed by system crashes. 4). Records in the system can be modified so that evidence can be changed. Computers can carry out anyone's orders, making it difficult to track down who the real culprit is. In the framework of the legal policy of criminal defamation through electronic social media,

Suggestions in this study are for law enforcement officers, punishment in criminal acts of defamation should pay attention to determining the weight of punishment (the level of sentencing), namely in determining appropriate sanctions for perpetrators based on the level of crime, the condition of the perpetrator and other circumstances so that there is no leveling (indiscriminately) on the imposition of a criminal. For the community, it is necessary to improve professional skills through discussion activities, seminars, upgrading or other scientific forums in the field of law, especially material criminal law and formal criminal law on an ongoing basis for investigators/assistant investigators by relevant agencies. In addition to promoting implementation/technical instructions from relevant law enforcement agencies regarding the implementation of the Criminal Procedure Code.

\section{References}

\section{Journal}

[1] A Chuasanga, Ong Argo Victoria. (2019). "Legal Principles Under Criminal Law in Indonesia \& Thailand", Jurnal Daulat Hukum, Vol 2, No 1 (2019) http://jurnal.unissula.ac.id/index.php/RH/article/view/4218 
[2] Adhe I smail A, "Constitutionalism Concept in Implementation of Indonesian State Administration". Jurnal Daulat Hukum Volume 4 Issue 2, June 2021 ISSN: 2614-560X.

[3] Ardito, Y P, Umar Ma'ruf \& Aryani Witasari. "Implementation of Criminal Action Prosecution Online in Realizing Principle of Fast Prosecution, Simple \& Low Cost", Jurnal Daulat Hukum, Volume 4 Issue 2, June 2021 ISSN: 2614-560X.

[4] Feri, S W, \& Arpangi. "Settlement Policy of Criminal Actions which Performed by Children through Penal Mediation". Jurnal Daulat Hukum Volume 4 Issue 2, June 2021 ISSN: 2614-560X.

[5] Nurfita A T, Sri Endah Wahyuningsih \& Arpangi. "The Police Role in Investigating the Crime of Child Murder as a Result of Infidelity Relationships". Law Development Journal ISSN : 2747-2604 Volume 3 Issue 1, March 2021.

[6] Sri Endah Wahyuningsih, 2014, "Urgensi Pembaharuan Hukum Pidana Materiel Indonesia Berdasarkan Nilai-Nilai Ketuhanan Yang Maha Esa”, Jurnal Pembaharuan Hukum Volume 1 No.1, Januari-April 2014.

[7] Yusril I A, Bambang Tri Bawono \& Ira Alia Maerani, "Criminal Investigation of Motorcycle Stealing Goods". Law Development Journal ISSN : 2747-2604 Volume 3 Issue 1, March 2021.

\section{Books}

[1] Al Wisnubroto, 1999. Kebijakan hukum pidana dalam penanggulangan penyalahgunaan komputer, Universitas Widyatama, Yogyakarta.

[2] Andi Hamzah, 1985. Pengantar Hukum Acara Pidana Indonesia. Ghalia Indonesia. Jakarta.

[3] Soerjono Soekanto, 2010, Pengantar Penelitian Hukum, Universitas Indonesia Press, Jakarta.

\section{Internet}

[1] http://media.kompasiana.com/new-media/2010/01/27/jangan-takutmenulis-dikompasiana

[2] Iskandar Zulkarnaen "Kronologi Kasus Prita Mulyasari" http://www.kompasiana.com/iskandarjet/kronologi-kasus-pritamulyasari 54fd5ee9a33311021750fb34

[3] "Kritik Kampus, Mahasiswa Semarang Dipaksa Mundur dalam http://www.tempo.co/read/news/2013/09/19/058514741/KritikKampus-Mahasiswa-Semarang-Dipaksa-Mundur

[4] "ICT: 71 Kasus Pidana Akibat UU ITE" http://nasional.tempo.co/read/news/2014/11/16/058622226/ICT-71Kasus-Pidana-Akibat-UU-ITE

[5] "Polisi Bebaskan Penghina Nurdin Halid" dalam http://www.tempo.co/read/news/2013/09/16/063513795 /polisiBebaskan-Penghina-Nurdin-Halid 